(International Journal of Agriculture and Wildlife Science)
http://dergipark.org.tr/ijaws

Research Article

\title{
The Effect of Shaker Use on Embryo Yield in Shed-Microspore Cultures of Ornamental Peppers**
}

\author{
Selcen Doğan*, Esin Arı \\ Akdeniz University, Faculty of Agriculture, Department of Agricultural Biotechnology, Antalya
}

Received: 01.10.2019 Accepted: 05.11.2019

\begin{abstract}
Keywords:
Anther, Capsicum annuum L., doubled haploid, microspore embryogenesis, culture shaking

\section{${ }^{*}$ Corresponding Author} doganselcen@gmail.com

Abstract. Because of their morphological diversity and various rich content, ornamental peppers (Capsicum annuum L.) has become a favored plant in ornamental plant, food, cosmetics and medicinal sectors in recent years. This interest increased the ornamental pepper breeding studies. However, there are limited numbers of study based on haploid technology in ornamental peppers. In this study, we aimed to determine the effect of using shaker on embryo yield in the shedmicrospore cultures of ornamental peppers. We used a total of 29 genotypes and compared the shaken and stationary cultures for each genotype. The shaken cultures gave more successful androgenic performance in terms of total and globular embryo formations. The most successful embryogenic performance was obtained from Genotype 754 in both stationary and shaken cultures. However, the shaken cultures of Genotype 754 formed 4.5 times more embryos when compared to its stationary control group. As the result, the use of shaker positively affected embryo yield in shedmicrospore cultures of ornamental pepper depending on genotype.
\end{abstract}

\section{Çalkalayıcı Kullanımının Süs Biberi Shed-Mikrospor Kültürlerinde Embriyo Verimine Etkisi}

\section{Anahtar kelimeler:}

Anter, Capsicum annuum L., doubled haploid, mikrospor embriyogenesis, çalkalama
Özet. Morfolojik çeşitlilikleri ve çeşitli zengin içerikleri nedeniyle süs biberleri (Capsicum annuum L.) son yıllarda süs bitkisi, gıda, kozmetik ve ilaç sektörlerinde tercih edilen bitkiler haline gelmiştir. Süs biberine olan bu ilgi süs biberinde yapılan ıslah çalışmalarını son yıllarda arttırmıştır. Ancak süs biberlerinde haploid teknolojisine dayalı sınırlı sayıda ıslah çalışması bulunmaktadır. Bu çalışmada, süs biberi shed-mikrospor kültürlerinde çalkalayıcı kullanımının embriyo verimi üzerine etkisi belirlenmeye çalışımıştır. Toplam 29 süs biberi genotipi kullanılmış ve her genotipin çalkalanan ve durağan kültürleri karşılaştııılmıştır. Çalkalanan kültürler, toplam ve globular embriyo oluşturma açısından daha başarılı androjenik performans göstermiştir. Çalışmada en başarılı embriyojenik performans, hem durağan hem çalkalanan kültürlerde Genotip 754'ten elde edilmiştir. Genotip 754'ün çalkalanan kültürleri, durağan kontrol grubuna kıyasla 4.5 kat daha fazla embriyo oluşturmuştur. Sonuç olarak, çalkalayıcı kullanımı, genotipe bağlı olarak süs biberi shed-mikrospor kültürlerinde embriyo verimini olumlu yönde etkilemiştir. 


\section{INTRODUCTION}

Capsicum annuum L. (Solanaceae) is one of the most cultivated and economical species in Capsicum genus in the world today. It is consumed freshly or dried in the kitchen and is utilized in the food industry as canned food, sauce, spice and pickle. Additionally, in the $C$. annuum species, the ones that have ornamental value have become favored for in landscaping due to their easy and fast growing traits, warm and drought tolerance and high fruit retention ratios (Stommel and Bosland, 2007). Thus, it is noteworthy that for all these reasons, suitable breeding studies for various pepper types have been emphasized all over the world and biotechnology, especially haploidy is widely used. In C. annuum, microspore embryogenesis based androgenic techniques are mostly used for the production of doubled haploids. However, the androgenesis studies in C. annuum are generally focused on edible varieties and studies for ornamental peppers are very few in the literature (Barraso et al., 2015; Arı et al., 2016a, 2016b).

In a review study, Segui-Simarro et al. (2011) stated that the most efficient results in microspore embryogenesis studies for pepper were gained from the protocols: (1) anther culture method introduced from Dumas de Vaulx et al. (1981), (2) two-phased method developed by Dolcet-Sanjuan et al. (1997), (3) two-phased stationary shed-microspore culture consisting of a solid medium layer with activated charcoal and a liquid medium layer improved by Supena et al. (2006b) and (4) isolated microspore culture method. However, due to genotype factor and embryo development difficulties, there is not still a routine used androgenesis protocol for pepper. Among these protocols, the stationary shed-microspore culture technique developed by Supena et al. (2006b) has become prominent with its practical application and high yield of embryos (Supena et al., 2006a, 2006b; Supena and Custers, 2011; Arı et al., 2016a, 2016b). Besides these advantages, in the solid phase of shedmicrospores culture, activated charcoal has some critical roles in embryo development. The pore structures of activated charcoal adsorb the toxic and phenolic components released from anther tissues and microspores in the liquid media. Also activated charcoal stores these substances inside their large internal volume. Thus, the adsorption of phenolics prevents the damages in culture material and provides a better output (Thomas, 2008). Supena et al. (2006b) pointed out that they got the higher numbers of total and normal looking healthy embryos from the activated carbon added stationary shed-microspore cultures of Indonesian hot peppers.

The shed-microspore culture can be regarded as a kind of anther culture in the liquid medium in terms of the development of microspores released from anther walls in the liquid medium of biphasic media. A better contact of explant with liquid media results in faster growth than with gel media. By providing agitation to liquid media, the explants use more efficiently the nutrients and growth regulators in the medium and accumulation of toxic metabolites near the explants efficaciously spread out (George, 1993). Kim et al. (2013) interpreted the reason of high yield of embryo development in liquid medium as the microspores in the liquid medium could reach the necessary nutrients more easily thanks to their freedom of movement. Another advantage of liquid medium to gels is its aeration opportunity (Smith and Spomer, 1995). Takahashi et al. (1992) demonstrated that agar-based medium suppressed the production of lily-bulblets. Conversely, the best propagule quality was obtained from the aeration optimized liquid tank cultures in their study.

The growing habits of some cultures are better in liquid media than on solid media. A gentle agitating with a rotator or a shaker may help to aeration of medium and so prevents the explants from submerging (Kyte and Kleyn, 1996). The advantages of shaken liquid cultures are noticed in various micropropagation studies with their high carbohydrate reserves, easy acclimatization abilities and better root developments. Among these, the results of shaken liquid cultures of Hosta tokudoma (Newberry Gold) and Hosta x hybrid Tratt. (Blue Cadet) (Adelberg et al., 2000; Adelberg, 2005), Colocasia esculenta L. Schott Fontanesii and Alocasia macrorrhizos G. Don (Adelberg and Toler, 2004), and Ophiopogon planiscapus 'Nigrescens' (Black Mondo) (Arı et al., 2015) are considerable.

In regard of haploidy studies, only Yang et al. (2013) examined the effect of shaker use. They compared the embryo formations and plant regeneration capacities of stationary Brassica rapa L. ssp chiensis microspore cultures and cultures on shakers with different frequencies ( $40 \mathrm{rpm}, 50 \mathrm{rpm}, 80 \mathrm{rpm}, 100 \mathrm{rpm}$ ). According to the results, embryos with higher quality and more regeneration capacities were obtained from the cultures on shakers with $50 \mathrm{rpm}$ frequency than the embryos obtained from stationary cultures.

There are a few haploidy studies (Barraso et al., 2015; Arı et al., 2016a, 2016b) in ornamental peppers. The increasing their embryo yields would help to improve the efficiency of ornamental pepper breeding programs. The aim of this study is to detect the effect of shaker use on embryo yield of 29 ornamental pepper genotypes' shed-microspore cultures. 


\section{MATERIAL AND METHOD}

\section{Plant Material}

The material for present study consisted of 29 ornamental pepper (Capsicum annuum L.) genotypes. From those, 25 genotypes were originated from cultivars encoded with (C) letter and 4 genotypes were originated from local cultivars encoded with (L) letter. The seeds of the plant material were procured from Pey-Art Ltd. located in Antalya, Turkey. The seeds of 29 ornamental pepper genotypes were planted in viols containing $10 \%$ vermiculite, $25 \%$ perlite and $65 \%$ peat mixture, then the developed seedlings were planted with a distance of $30 \mathrm{~cm}$ as row distance and $80 \mathrm{~cm}$ between two seedlings in a high plastic greenhouse in Antalya in spring. The plants fertilized with NPK (15-15-18\% w/w) by drip irrigation in every two weeks. Despite not being recommended; an insecticide has been applied only once due to intensive pest attack.

The proper ornamental pepper buds having appropriate staged microspores as described by Arı et al. (2016b) were used as material. We detected the stages of microspores by using 4',6-diamidino-2-phenylindole (DAPI) staining technique (Sigma-Aldrich, St. Louis, MO, USA) as Coleman and Goff (1985) and Kim and Jang (2000) described. The candidate buds were collected in falcon tubes from the greenhouse between 8 am and 9 am in the morning and were kept cold until arrival at the laboratory. Subsequently, the buds were treated at $4^{\circ} \mathrm{C}$ for 24 $\mathrm{h}$ and then sterilized in $15 \%$ commercial bleach added with Tween 20 for $10 \mathrm{~min}$, lastly rinsed with sterile $\mathrm{dH}_{2} \mathrm{O}$ for three times. As culture material, the anthers of the genotypes were isolated from the buds under stereomicroscope in sterile laminar flow.

\section{Media and Culture Conditions}

The anthers (5-7) of each disinfected bud were sown in the two phased shed-microspore culture media which was the combination of Supena et al. (2006b) and Supena and Custers (2011) with minor amendments. The culture medium, in which the solid and liquid phases coexist, consists of the Nitsch and Nitsch (NN) (1969) components both in the liquid medium at the upper layer and solid medium at the under layer. The solid under layer was consisted of NN components with the addition of $2 \%$ maltose, $1 \%$ activated charcoal and $0.6 \%$ plant agar. The upper liquid layer was composed of NN liquid medium with $2 \%$ maltose, filter-sterilized $2.5 \mu \mathrm{M}$ zeatin and $5 \mu \mathrm{M}$ IAA (indole-3-acetic acid). Although Supena and Custers (2011) added zeatin and IAA in liquid medium 3 weeks after the incubation in their protocol, in our study, zeatin and IAA was added to the liquid medium before incubation to avoid contamination risk as used by Arı et al. (2016a, 2016b). The pH of the both medium was adjusted to 5.8 and autoclaved at $121^{\circ} \mathrm{C}$ for $20 \mathrm{~min}$., and then poured on petri dishes (60 mm in diameter; with solid layer containing $4 \mathrm{~mL}$ and liquid layer containing 5-6 mL).

As culture conditions, anthers from each bud were placed in one petri dish and incubated at $9{ }^{\circ} \mathrm{C}$ for one week. Afterwards, from the 10 petri dishes prepared for each genotype, 5 petri dishes were left stationary state for control and 5 were placed on an orbital shaker at $50 \mathrm{rpm}$ per min for 3 weeks at $28^{\circ} \mathrm{C}$ in continuous darkness. Lastly, the stationary and shaken cultures were transferred to $21^{\circ} \mathrm{C}$ for $3-5$ weeks in the dark.

\section{Statistical Analysis}

The experiment was repeated 3 times for stationary and shaken groups. The whole data were collected after 8 weeks of culture. The information of average numbers of total and normal-looking embryos for each genotype of stationary and shaken cultures were recorded. The averages of total and normal-looking embryo as per bud were evaluated as Supena et al. (2006a, 2006b) and Ari et al. (2016a, 2016b) described in their studies. One-way analysis of variance (ANOVA) was applied to define the differences in applications and genotypes. The data were normalized prior to analysis by Sqrt $(x+0.5)$, where $x$ represents the number of embryos per bud in order to encounter the assumptions of ANOVA. The general linear model procedure of SPSS (Statistics 20) software (IBM Corp., Armonk, NY, USA) was used for data analyses. All main effects were considered as fixed effects. Multiple comparisons of the genotypes were performed by using Tukey's multiple range post hoc test at an alpha 0.05 level.

\section{RESULTS}

\section{Shed-microspore Culture of Stationary Cultures}

According to ANOVA results it was found that genotypes differ from each other statistically $(p<0.001)$ in the mean number of both total and normal looking embryos per bud. However, there was no significant difference between stationary and shaken cultures. 
As given in Table 1, of the 29 genotypes, 13 were responsive to shed-microspore culture in stationary cultures. Between 0.14 and 4.69 embryos per bud were obtained from these 13 genotypes (Table 1). Statistically, the commercial originated genotype 754 had the highest performance (4.69 embryos per bud) and it was determined that this genotype was statistically different from the other genotypes. This genotype was followed by genotypes 735 and 283 with an average of 2.17 and 2.00 embryos per bud, respectively. In terms of average number of normal-looking embryos per bud, the highest formation of normal-looking embryos were obtained from local genotype 735 with a value of 0.67 embryos per bud.

Table 1. Comparison of the androgenic responses of stationary and shaken shed-microspore cultures of 29 ornamental pepper genotypes.

Çizelge 1. 29 süs biber genotipinin durağan ve çalkalanan kültürlerindeki androjenik tepkilerinin karşılaştırılması.

\begin{tabular}{|c|c|c|c|c|c|}
\hline \multirow{4}{*}{$\begin{array}{l}\text { Origin of } \\
\text { the } \\
\text { Genotype* }\end{array}$} & \multirow{4}{*}{ Genotype } & \multicolumn{4}{|c|}{ Average yield of embryos per flower bud } \\
\hline & & \multicolumn{2}{|c|}{ No. of total embryos produced } & \multicolumn{2}{|c|}{ No. of total normal-looking embryos produced } \\
\hline & & Stationary cultures & Shaken cultures & Stationary cultures & Shaken cultures \\
\hline & & $\mathbf{M} \pm \mathrm{SE}^{* *}$ & $\mathbf{M} \pm \mathbf{S E}$ & $\mathbf{M} \pm \mathbf{S E}$ & $\mathbf{M} \pm \mathbf{S E}$ \\
\hline \multirow[t]{2}{*}{$\mathrm{C} 1$} & 3 & $0.00 \pm 0.00^{c}$ & $0.00 \pm 0.00^{b}$ & $0.00 \pm 0.00^{c}$ & $0.00 \pm 0.00^{b}$ \\
\hline & 17 & $0.14 \pm 0.14 b c$ & $0.00 \pm 0.00^{b}$ & $0.00 \pm 0.00^{c}$ & $0.00 \pm 0.00^{b}$ \\
\hline $\mathrm{C} 2$ & 34 & $1.00 \pm 0.54 \mathrm{bc}$ & $0.00 \pm 0.00^{b}$ & $0.27 \pm 0.15^{a b c}$ & $0.00 \pm 0.00^{b}$ \\
\hline $\mathrm{C3}$ & 47 & $0.69 \pm 0.40^{b c}$ & $0.00 \pm 0.00^{b}$ & $0.08 \pm 0.08 \mathrm{abc}$ & $0.00 \pm 0.00^{b}$ \\
\hline \multirow[t]{2}{*}{ C4 } & 54 & $0.00 \pm 0.00^{c}$ & $0.00 \pm 0.00^{b}$ & $0.00 \pm 0.00^{c}$ & $0.00 \pm 0.00^{b}$ \\
\hline & 96 & $0.00 \pm 0.00^{c}$ & $0.00 \pm 0.00^{b}$ & $0.00 \pm 0.00^{c}$ & $0.00 \pm 0.00^{b}$ \\
\hline $\mathrm{C} 5$ & 107 & $0.00 \pm 0.00^{c}$ & $0.00 \pm 0.00^{b}$ & $0.00 \pm 0.00^{c}$ & $0.00 \pm 0.00^{b}$ \\
\hline C6 & 108 & $0.57 \pm 0.40^{b c}$ & $0.00 \pm 0.00^{b}$ & $0.07 \pm 0.07^{b c}$ & $0.00 \pm 0.00^{b}$ \\
\hline \multirow[t]{2}{*}{$\mathrm{C} 8$} & 127 & $0.00 \pm 0.00^{c}$ & $0.00 \pm 0.00^{b}$ & $0.00 \pm 0.00^{c}$ & $0.00 \pm 0.00^{b}$ \\
\hline & 132 & $0.00 \pm 0.00^{c}$ & $0.00 \pm 0.00^{b}$ & $0.00 \pm 0.00^{c}$ & $0.00 \pm 0.00^{b}$ \\
\hline \multirow[t]{6}{*}{ C9 } & 419 & $0.00 \pm 0.00^{c}$ & $0.00 \pm 0.00^{b}$ & $0.00 \pm 0.00^{c}$ & $0.00 \pm 0.00^{b}$ \\
\hline & 143 & $0.00 \pm 0.00^{c}$ & $0.00 \pm 0.00^{b}$ & $0.00 \pm 0.00^{c}$ & $0.00 \pm 0.00^{b}$ \\
\hline & 146 & $0.00 \pm 0.00^{c}$ & $0.00 \pm 0.00^{b}$ & $0.00 \pm 0.00^{c}$ & $0.00 \pm 0.00^{b}$ \\
\hline & 155 & $0.00 \pm 0.00^{c}$ & $0.00 \pm 0.00^{b}$ & $0.00 \pm 0.00^{c}$ & $0.00 \pm 0.00^{b}$ \\
\hline & 166 & $0.00 \pm 0.00^{c}$ & $0.00 \pm 0.00^{b}$ & $0.00 \pm 0.00^{c}$ & $0.00 \pm 0.00^{b}$ \\
\hline & 174 & $0.00 \pm 0.00^{c}$ & $0.00 \pm 0.00^{b}$ & $0.00 \pm 0.00^{c}$ & $0.00 \pm 0.00^{b}$ \\
\hline $\mathrm{C} 10$ & 230 & $0.47 \pm 0.27^{b c}$ & $0.00 \pm 0.00^{b}$ & $0.00 \pm 0.00^{c}$ & $0.00 \pm 0.00^{b}$ \\
\hline \multirow[t]{2}{*}{ C11 } & 283 & $2.00 \pm 0.79 a b$ & $1.23 \pm 0.90^{b}$ & $0.20 \pm 0.14 a b c$ & $0.23 \pm 0.17^{b}$ \\
\hline & 292 & $0.27 \pm 0.21^{b c}$ & $0.00 \pm 0.00^{b}$ & $0.00 \pm 0.00^{c}$ & $0.00 \pm 0.00^{b}$ \\
\hline $\mathrm{C} 12$ & 313 & $1.27 \pm 0.40^{a b c}$ & $0.57 \pm 0.39^{b}$ & $0.27 \pm 0.12^{a b c}$ & $0.00 \pm 0.00^{b}$ \\
\hline \multirow[t]{2}{*}{ C13 } & 324 & $0.07 \pm 0.07^{b c}$ & $0.00 \pm 0.00^{b}$ & $0.07 \pm 0.07^{b c}$ & $0.00 \pm 0.00^{b}$ \\
\hline & 330 & $0.00 \pm 0.00^{c}$ & $0.00 \pm 0.00^{b}$ & $0.00 \pm 0.00^{c}$ & $0.00 \pm 0.00^{b}$ \\
\hline C14 & 337 & $0.00 \pm 0.00^{c}$ & $0.00 \pm 0.00^{b}$ & $0.00 \pm 0.00^{c}$ & $0.00 \pm 0.00^{b}$ \\
\hline C18 & 383 & $0.27 \pm 0.19 b c$ & $0.38 \pm 0.38^{b}$ & $0.00 \pm 0.00^{c}$ & $0.08 \pm 0.08^{b}$ \\
\hline $\mathrm{C} 20$ & 754 & $4.69 \pm 2.33^{a}$ & $20.4 \pm 9.76^{a}$ & $0.46 \pm 0.22^{a b}$ & $1.27 \pm 0.44^{a}$ \\
\hline L1 & 441 & $0.00 \pm 0.00^{c}$ & $0.00 \pm 0.00^{b}$ & $0.00 \pm 0.00^{c}$ & $0.00 \pm 0.00^{b}$ \\
\hline L5 & 564 & $0.00 \pm 0.00^{c}$ & $0.13 \pm 0.13^{b}$ & $0.00 \pm 0.00^{c}$ & $0.00 \pm 0.00^{b}$ \\
\hline L12 & 707 & $0.31 \pm 0.31 b c$ & $0.00 \pm 0.00^{b}$ & $0.00 \pm 0.00^{c}$ & $0.00 \pm 0.00^{b}$ \\
\hline L16 & 735 & $2.17 \pm 2.17 \mathrm{abc}$ & $3.15 \pm 3.15^{b}$ & $0.67 \pm 0.67^{a}$ & $0.08 \pm 0.08^{b}$ \\
\hline
\end{tabular}

*Letter $C$ and $L$ symbolizes commercial and local cultivars, respectively.

${ }^{* *}$ Values are mean and standard error (SE). Means were separated by using Tukey's multiple range post hoc test. Different letters near the means represent significant difference at $\mathrm{P} \leq 0.05$.

The total number of embryos obtained from genotypes 754, 283 and 735, which were recorded to have the best performance, were determined to be 61,30 and 13, respectively (Table 2). The normal looking embryos were developed again mostly from genotype 754 . Among the total embryos, those that could not transform into 
normal looking embryos with two cotyledons either remained in globular shape or showed abnormal growth such as embryos with only one cotyledon.

When the embryo yield of stationary cultures was evaluated in general, a total of 177 embryos obtained from 13 genotypes, of which 63 were in the globular stage, 90 embryos with one cotyledon and 24 normal-looking embryos with two cotyledons (Table 2).

Table 2. The number of total, globular, abnormal (with one cotyledon) and normal-looking (with two cotyledons) embryos from the stationary and shaken shed-microspore cultures of 29 ornamental pepper genotypes.

Çizelge 2. 29 süs biberi genotipinin durağan ve çalkalanan kültürlerindeki toplam, globular, anormal (tek kotiledonlu) ve normal görünümlü embriyo saylları.

\begin{tabular}{|c|c|c|c|c|c|c|c|c|c|}
\hline \multirow{2}{*}{$\begin{array}{c}\text { Origin of } \\
\text { the } \\
\text { Genotype* }\end{array}$} & \multirow{2}{*}{ Genotype } & \multicolumn{2}{|c|}{$\begin{array}{l}\text { No. of total } \\
\text { embryos }\end{array}$} & \multicolumn{2}{|c|}{$\begin{array}{l}\text { No. of globular } \\
\text { embryos }\end{array}$} & \multicolumn{2}{|c|}{$\begin{array}{c}\text { No. of } \\
\text { abnormal } \\
\text { embryos with } \\
\text { one cotyledon }\end{array}$} & \multicolumn{2}{|c|}{$\begin{array}{c}\text { No. of normal- } \\
\text { looking embryos } \\
\text { with two } \\
\text { cotyledons }\end{array}$} \\
\hline & & 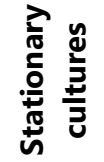 & 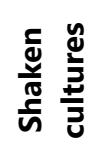 & 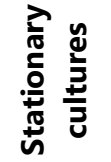 & 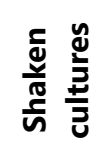 & 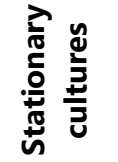 & 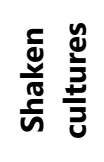 & 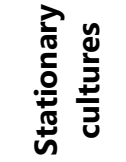 & 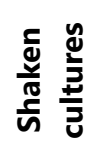 \\
\hline \multirow[t]{2}{*}{ C1 } & 3 & 0 & 0 & 0 & 0 & 0 & 0 & 0 & 0 \\
\hline & 17 & 2 & 0 & 2 & 0 & 0 & 0 & 0 & 0 \\
\hline C2 & 34 & 15 & 0 & 8 & 0 & 3 & 0 & 4 & 0 \\
\hline C3 & 47 & 10 & 0 & 1 & 0 & 8 & 0 & 1 & 0 \\
\hline \multirow[t]{2}{*}{$\mathrm{C} 4$} & 54 & 0 & 0 & 0 & 0 & 0 & 0 & 0 & 0 \\
\hline & 96 & 0 & 0 & 0 & 0 & 0 & 0 & 0 & 0 \\
\hline $\mathrm{C} 5$ & 107 & 0 & 0 & 0 & 0 & 0 & 0 & 0 & 0 \\
\hline $\mathrm{C} 6$ & 108 & 8 & 0 & 3 & 0 & 4 & 0 & 1 & 0 \\
\hline \multirow[t]{2}{*}{$\mathrm{C} 8$} & 127 & 0 & 0 & 0 & 0 & 0 & 0 & 0 & 0 \\
\hline & 132 & 0 & 0 & 0 & 0 & 0 & 0 & 0 & 0 \\
\hline \multirow[t]{6}{*}{ C9 } & 419 & 0 & 0 & 0 & 0 & 0 & 0 & 0 & 0 \\
\hline & 143 & 0 & 0 & 0 & 0 & 0 & 0 & 0 & 0 \\
\hline & 146 & 0 & 0 & 0 & 0 & 0 & 0 & 0 & 0 \\
\hline & 155 & 0 & 0 & 0 & 0 & 0 & 0 & 0 & 0 \\
\hline & 166 & 0 & 0 & 0 & 0 & 0 & 0 & 0 & 0 \\
\hline & 174 & 0 & 0 & 0 & 0 & 0 & 0 & 0 & 0 \\
\hline $\mathrm{C} 10$ & 230 & 7 & 0 & 4 & 0 & 3 & 0 & 0 & 0 \\
\hline \multirow[t]{2}{*}{ C11 } & 283 & 30 & 16 & 13 & 6 & 14 & 7 & 3 & 3 \\
\hline & 292 & 4 & 0 & 4 & 0 & 0 & 0 & 0 & 0 \\
\hline $\mathrm{C} 12$ & 313 & 19 & 8 & 5 & 8 & 10 & 0 & 4 & 0 \\
\hline \multirow[t]{2}{*}{$\mathrm{C} 13$} & 324 & 1 & 0 & 0 & 0 & 0 & 0 & 1 & 0 \\
\hline & 330 & 0 & 0 & 0 & 0 & 0 & 0 & 0 & 0 \\
\hline C14 & 337 & 0 & 0 & 0 & 0 & 0 & 0 & 0 & 0 \\
\hline $\mathrm{C} 18$ & 383 & 3 & 5 & 1 & 0 & 2 & 4 & 0 & 1 \\
\hline $\mathrm{C} 20$ & 754 & 61 & 306 & 17 & 230 & 38 & 57 & 6 & 19 \\
\hline L1 & 441 & 0 & 0 & 0 & 0 & 0 & 0 & 0 & 0 \\
\hline L5 & 564 & 0 & 2 & 0 & 2 & 0 & 0 & 0 & 0 \\
\hline L12 & 707 & 4 & 0 & 0 & 0 & 4 & 0 & 0 & 0 \\
\hline \multirow[t]{2}{*}{ L16 } & 735 & 13 & 41 & 5 & 30 & 4 & 10 & 4 & 1 \\
\hline & Total & 177 & 378 & 63 & 276 & 90 & 78 & 24 & 24 \\
\hline
\end{tabular}

*Letter C and L symbolizes commercial and local cultivars, respectively. 


\section{Shed-microspore Culture of Shaken Cultures}

As given in Table 1, of the 29 genotypes, 6 were responsive to shed-microspore culture in the shaken cultures. Between 0.13 and 20.4 embryos per bud were obtained from these 6 genotypes. The genotype 754 with commercial origin apparently produced the highest number of total (20.4 embryos per bud) and normal-looking embryos (1.27 embryos per bud) and distinguished from the other genotypes. This genotype was followed by genotypes with an average of 3.15 and 1.23 total embryos per bud, respectively, from local genotype 735 and genotype 283 with commercial origin. In terms of producing normal-looking embryos, the highest average per bud was obtained from 754 with a value of 1.27 .

The total number of embryos obtained from genotypes 754,735 and 283, which had the best performance, were determined to be 306,41 and 16, respectively (Table 2). The highest transition to normal looking embryos was observed in genotype 754. As in the stationary cultures, the embryos that could not normally develop, stayed in globular stage or developed abnormally.

In terms of embryo production of shaken cultures, a total of 378 embryos obtained from 6 genotypes, of which 276 were in the globular stage, 78 embryos with one cotyledon and 24 normal-looking embryos with two cotyledons (Table 2). After one month of culture when the embryos appeared in the medium, in the shaken cultures, the normal-looking embryos were kept in the medium to complete their developments. However, these embryos turned into brownish color and died in a short span of time.

\section{DISCUSSION}

In androgenesis studies, the genotype is accepted as one of the most important factor for the androgenic response of microspores (Segui-Simarro, 2010). The tendency to microspore embryogenesis may vary in different plant varieties even they are in the same species. Some variants do not respond microspore embryogenesis at all, while some highly response (Ferrie et al., 1995; Touraev et al., 2001; Malik et al., 2008; Segui-Simarro, 2010). Also in this study, genotype had a very significant effect in terms of total embryo and normal-looking embryo formations $(p \leq 0.001)$. The results agree with those obtained by Arı et al. $(2016 \mathrm{a}, 2016 \mathrm{~b})$ and by Barraso et al. (2015) working on haploid embryogenesis in different ornamental pepper genotypes.

In regard to culture type, there was no significant difference between the stationary and shaken cultures in the study. The genotype 754 became prominent in terms of average yield of total and normal-looking embryo formations in both stationary and shaken culture which shows again the dominant effect of genotype. We detected about 4.5 times more average yield of total embryo formation in the shaken cultures of genotype 754 in comparison to its stationary group. The number of embryos per bud of genotype 754 increased from 4.69 to 20.4. This result agrees with the findings of Yang et al. (2013) who revealed the positive results of shaker use on microspore embryogenesis. In their study, of the 7 tested genotypes belongs to Brassica rapa L. ssp. chinensis, the microspore embryogenesis and embryo development performances were higher in shaken cultures when compared to their stationary control groups. In particular, shaking culture success of the varieties of Huaguan and YSO7 significantly increased in comparison to the stationary culture. The number of embryos per bud increased from 1.87 to 3.13 in Huaguan while from 24.00 to 28.53 in YS07, the most responsive variety. Six of the 29 ornamental pepper genotypes tested in our study showed positive responsive to the shaken cultures. Thus, we deduced that shaking cultures could strongly enhance microspore embryogenesis in ornamental pepper. However, this influence had quite strong genotype-dependent effect.

In terms of normal-looking embryo formation, the transition rates of embryos to normal-looking embryos in stationary and shaken cultures were $6.34 \%$ and $13.56 \%$ respectively. From this point, the positive results of shaker use were also compatible with Yang et al. (2013). On the other hand, the normal-looking embryo formations were generally in low ratios both in stationary and shaken cultures in our study. The normal healthy embryos with two cotyledons that were kept waiting for a better development at $21{ }^{\circ} \mathrm{C}$ in dark conditions soon became brown and lost their vitality especially in shaken cultures. This circumstance was seen also in the globular embryos of shaken cultures. One month after the culturing process, the globular embryos were apparent in the cultures of both applications. However most of the globular embryos in the shaken cultures could not complete their development, stopped their maturation.

In the literature, there are limited number of studies focusing on the effects of shaker use on haploidy performance but there are more in other plant tissue culture studies. For instance, Raghuvanshi and Srivastava [1995] introduced positive effects of shaker use on micropropagation of mango. They solved the problem of phenolic-derived browning in explants by pretreating them in liquid medium on an automated shaker and refreshing the medium at certain intervals. Their work showed that pretreating explants in liquid shaker culture 
and medium renovation helped to remove the phenolic exudates in mango thereby provided a better micropropagation.

The importance of culture medium renovation on embryo formation and regeneration were also revealed in several haploidy studies. Dias and Correia (2002) reported the positive effect of culture medium renovation on tronchuda cabbage "Couve Algarvia" microspore culture embryogenesis. The responsiveness to microspore embryogenesis increased when the medium was renewed. Li and Devaux (2003) reported that embryo development and regeneration capacities of Hordeum vulgare L. microspores incubated in liquid medium for 3 weeks and then in solid medium for 3 weeks were higher than cultures incubated only in liquid medium for 6 weeks. They stated that renewing the culture media allows the embryos to ventilate better and to develop in a healthier direction. The benefit of medium renovation on embryo yield is also revealed by Wei et al. (2008) in a study of isolated microspore culture of ornamental kale (Brassica oleracea var. acephala). They observed clusters of brown/dead cells on microspore suspensions cultures of not renewed medium while cells were alive where medium was renovated. In addition, Kim et al. (2013) showed the positive effects of media change on haploid performance of a hot pepper genotype (C. annuum L. CV. Milyang-jare) for microspore embryogenesis. They stated that liquid media have positive effects on embryo nutrient transport, but at the same time toxic and growth inhibiting substances are easily transported from the media to the embryos. Thereby, they reported that refreshing culture medium helps to dilute the detrimental compounds and reduces the negative effects of these harmful materials on embryo development.

When all these studies were considered, one possible reason of low embryo yield in our study can be explained by the fact that the anthers and microspores dispersed from the anthers in liquid medium were cultured in the same medium for about 2 months from the beginning. Thus, medium renovation at some intervals might contribute embryo quality and development for the future liquid culture studies in ornamental peppers.

As another important factor affecting androgenesis response, the donor plant growth conditions have a crucial role to induce haploid embryogenesis. The importance of this factor was underlined by Supena et al. (2006b). They emphasized that to obtain healthy buds is only possible from the plants grown in fully controlled phytotrones. In the present study, the donor plants were grown in a greenhouse and an insecticide had to be applied only once because of necessity. According to Custers (2003), the vitality of microspores is negatively affected from pesticides whether it is applied as spray or from soil. As Ferrie and Caswell (2011) stated, the essential condition in obtaining a successful and consistent microspore culture is using healthy and pesticide free donor plants.

\section{CONCLUSION}

Demand and interest in ornamental peppers due to their economic potential also increased the breeding studies on these plants. However, there are very few breeding studies using haploidy technique. In this study, the effect of shaker use on embryo yield was determined by using shed-microspore culture method based on haploidy technique. The shaken cultures gave more successful androgenic performance in terms of total and globular embryo formations. The use of shaker in shed-microspore cultures of ornamental peppers has positive effect on embryo yield, but this effect is genotype-dependent. In future studies, embryo yield in shaken cultures might be improved by cultivation of donor plants under controlled conditions and renovating the liquid medium of cultures at certain intervals.

\section{ACKNOWLEDGMENT}

This work has been supported by the Scientific and Technological Research Council of Turkey as part of the project 5120019-TUBITAK-TEYDEB-1505.

\section{REFERENCES}

Adelberg, J., Kroggel, M., \& Toler, J. (2000). Physical environment in vitro affects laboratory and nursery growth of micropropageted hostas. Hort Technology, 10(4), 754-757.

Adelberg, J., \& Toler, J. (2004). Comparison of agar and an agitated, thin-film, liquid system for micropropagation of ornamental elephant ears. Hort Science, 39(5), 1088-1092.

Adelberg, J. (2005). Efficiency in thin-film liquid system for Hosta micropropagation. Plant Cell, Tissue and Organ Culture, 81(3), 359-368. 
Ari, E., Adelberg, J., Delgado, M., \& Kroggel, M. (2015). Selection of the best black mondi (Ophiopogon planiscapus 'Nigrescens') clone in tissue culture conditions for micropropagation. Acta Horticulturae, 1087, 423-428.

Ari, E., Yildirim, T., Mutlu, N., Buyukalaca, S., Gokmen, U., \& Akman, E. (2016a). Comparison of different androgenesis protocols for doubled haploid plant production in ornamental pepper (Capsicum annuum L.). Turkish Journal of Biology, 40, 944-954.

Ari, E., Bedir, H., Yildirim, S., \& Yildirim, T. (2016b). Androgenic responses of 64 ornamental pepper (Capsicum annuum L.) genotypes to shed-microspore culture in autumn season. Turkish Journal of Biology, 40, 706-717.

Bajaj, Y. P. S. (1990). In vitro production of haploids and their use in cell genetics and plant breeding. In Y. P. S. Bajaj (Ed.), Biotechnology in Agriculture and Forestry 12, Haploids in Crop Improvement I (pp.3-44). Berlin: Springer.

Barroso, P.A., Rego, M.M., Rego, E.R., \& Soares, W.S. (2015). Embryogenesis in the anthers of different ornamental pepper (Capsicum annuum L.) genotypes. Genetics and Molecular Research, 14(4), 13349-13363.

Coleman, A.W., \& Goff, L.J. (1985). Applications of fluorochromes to pollen biology. I. Mithramycin and 4',6-diamidino-2phenylindole (DAPI) as vital stains and for quantitation of nuclear DNA. Biotechnic and Histochemistry, 60(3), $145-154$.

Custers, J. B. M. (2003). Microspore culture in rapeseed (Brassica napus L.). In M. Maluszynski, K. J. Kasha, B.P. Forster, \& I. Szarejko (Eds.), Doubled Haploid Production in Crop Plants A Manual (pp.185-193). Dodrecht: Kluwer Academic Publishers.

Dias, J. S., \& Correia, M. S. (2002). Effect of medium renovation and incubation temperature regimes on tronchuda cabbage microspore culture embryogenesis. Scientia Horticulturae, 93(3-4), 205-214.

Dolcet-Sanjuan, R., Claveria, E., \& Huerta, A. (1997). Androgenesis in Capsicum annuum L. effects of carbohydrate and carbon dioxide enrichment. Journal of the American Society for Horticultural Science, 122(4), 468-475.

Dumas De Vaulx, R., Chambonnet, D., \& Pochard, E. (1981). In vitro culture of pepper (Capsicum annuum L.) anthers: high rate plant production from different genotypes by $+35^{\circ} \mathrm{C}$ treatments haploid and diploid plants, cultivars. Agronomy for Sustainable Development, 1(10), 859-864.

Ellialtioglu, S., Sari, N., \& Abak, K. (2001). Haploid Bitki Uretimi. In M. Babaoglu, E. Gurel, \& S. Ozcan, S. (Eds), Bitki Biyoteknolojisi Cilt:I (pp. 138-189). Konya: Selçuk Üniversitesi Vakfı Yayınları.

Ferrie, A. M. R., Palmer, C. E., \& Keller, W.A. (1994). Biotechnological applications of haploids. In P. D. Shargool, \& T. T. Ngo (Eds), Biotechnological Applications of Plant Cultures (pp. 77-110). Boca Raton, Florida: CRC Press.

Ferrie, A. M. R., Palmer, C.E., \& Keller, W.A. (1995). Haploid embryogenesis. In T. A. Thorpe (Ed), In vitro Embryogenesis in Plants (pp. 244-309). Dordrecht: Springer.

Ferrie, A. M. R., \& Caswell, K. L. (2011). Isolated microspore culture techniques and recent progress for haploid and doubled haploid plant production. Plant Cell Tissue Organ Culture, 104(3), 301-309.

George, E. F. (1993). Plant Propagation by Tissue Culture Part 1: The Technology. Exegetics Limited, Edition: 2, UK.

Kim, M., \& Jang, J.C. (2000). Rapid assessment of microspore development stage in pepper using DAPI and ferric chloride. Journal of Plant Biotechnology, 2, 129-134.

Kim, M., Park, E-J., An, D., \& Lee, Y. (2013). High-quality embryo production and plant regeneration using a two-step culture system in isolated microspore cultures of hot pepper (Capsicum annuum L.). Plant Cell Tissue and Organ Culture, 112(2), 191-201.

Kyte, L., \& Kleyn, J. (1996). Plant from test tubes an introduction to micropropagation. Timber Press, Edition: 3, Portland (OR), USA.

Li, H., \& Devaux, P. (2003). High frequency regeneration of barley doubled haploid plants from isolated microspore culture. Plant Science, 164, 379-386.

Malik, M. R., Wang, F., Dirpaul, J. M., Zhou, N., Hammerlindl, J., Keller, W., Abrams, S. R., Ferrie, A. M. R., \& Krochko, J.E. (2008). Isolation of an embryogenic line from non-embryogenic Brassica napus cv. Westar through microspore embryogenesis. Journal of Experimental Botany, 59(10), 2857-2873.

Maluszynski, M., Kasha, K. J., \& Szarejko, I. (2003). Published doubled haploid protocols in plant species. In M. Maluszynski, K. J. Kasha, B.P. Forster, \& I. Szarejko (Eds.), Doubled Haploid Production in Crop Plants A Manual (pp. 309-335). Dodrecht: Kluwer Academic Publishers.

Murovec, J., \& Bohanec, B. (2012). Haploids and doubled haploids in plant breeding. In I. Abdurakhmonov (Ed.), Plant Breeding (pp. 87-106). InTech.

Nitsch, J. P., \& Nitsch, C. (1969). Haploid plants from pollen grains. Science, 163(3862), 85-87.

Palmer, C. E., \& Keller, W.A. (1999). Haploidy. In C. Gómez-Campo (Ed.), Biology of Brassica coenospecies (pp. 247-286). Amsterdam: Elsevier. 
Raghuvanshi, S. S., \& Srivastava, A. (1995). Plant regeneration of Mangifera indica using liquid shaker culture to reduce phenolic exudation. Plant Cell, Tissue and Organ Culture, 41(1), 83-85.

Segui-Simarro, J. M. (2010). Androgenesis revisited. The Botanical Review, 76(3), 377-404.

Segui-Simarro, J. M., Corral-Martinez, P., Parra-Vega, V., \& Gonzalez-Garcia, B. (2011). Androgenesis in recalcitrant solanaceous crops. Plant Cell Reports, 30(5), 765-778.

Smith, M. A. L., \& Spomer, L. A. (1995). Vessels, gels, liquid media and support systems. In J. Aitken-Christie, T. Kozai,\& M. A. L. Smith (Eds.), Automation and Environmental Control in Plant Tissue Culture (pp. 371-405). Dordrecht: Kluwer Academic Publishers.

Stommel, J. R., \& Bosland, P. W. (2007). Ornamental pepper. In N. O. Anderson (Ed.), Flower Breeding and Genetics - Issues, Challenges and Opportunities for the 21st Century (pp. 561-599). Dordrecht: Springer.

Supena, E. D. J. (2004). Innovations in microspore embryogenesis in Indonesian hotpepper (Capsicum annuum L.) and Brassica napus $L$. PhD Thesis, Wageningen University, Wageningen.

Supena, E. D. J., Muswita, W., Suharsono, S., \& Custers, J. B. (2006a). Evaluation of crucial factors for implementing shedmicrospore culture of Indonesian hot pepper (Capsicum annuum L.) cultivars. Scientia Horticulturae, 107(3), $226-232$.

Supena, E. D .J., Suharsono, S., Jacobsen, E., \& Custers, J. B. (2006b). Successful development of a shed-microspore culture protocol for doubled haploid production in Indonesian hot pepper (Capsicum annuum L.). Plant Cell Reports, 25(1), 1-10.

Supena, E. D. J., \& Custers, J. B. (2011). Refinement of shed-microspore culture protocol to increase normal embryos production in hot pepper (Capsicum annuum L.). Scientia Horticulturae, 130(4), 769-774.

Takahashi, S., Matsubara, K., Yamagata, H., \& Morimoto, T. (1992). Micropropagation of virus free bulblets of Lilium longiflorum by tank culture. 1. Development of liquid culture method and large scale propagation. Acta Horticulturae, 319(7), 83-88.

Thomas, T. D. (2008). The role of activated charcoal in plant tissue culture. Biotechnology Advances, 26(6), 618-631.

Touraev, A., Pfosser, M., \& Heberle-Bors, E. (2001). The microspore: A haploid multipurpose cell. Advances in Botanical Research, 35, 53-109.

Wei, Z., Qiang, F., Xigang, D., \& Manzhu, B. (2008). The culture of isolated micropores of ornamental kale (Brassica oleracea var. acephala) and the importance of genotype to embryo regeneration. Scientia Horticulturae, 117(1), 69-72.

Yang, S., Liu, X., Fu, Y., Zhang, X., Li, Y., Liu, Z., \& Feng, H. (2013). The effect of culture shaking on microspore embryogenesis and embryonic development in Pakchoi (Brassica rapa L. ssp. chinensis). Scientia Horticulturae, 152, 70-73. 